\title{
Structure Determination of Compounds from the Bark of Ficus ingens (Miq.) Miq.
}

\author{
Diriba Borena $^{1 *} \quad$ Hailemichael Tesso ${ }^{2} \quad$ Tariku Nefo $^{3}$ \\ 1. Diriba Borena, Horo Guduru Wollega Zone, Shambu preparatory school, P. O. Box 88, Shambu, Ethiopia. \\ 2.Department of chemistry, College of natural and computational sciences, Adama Science and Technology \\ University, P.O. Box: 1888, Adama, Ethiopia. \\ 3.Department of chemistry, College of natural and computational sciences, University of Wolaita Sodo, P.O. \\ Box, 138, Ethiopia.
}

\begin{abstract}
This study was carried out to investigate chemical constituents on the bark of Ficus ingens (Miq.) Miq. Three compounds were isolated from methanol extract of the bark Ficus ingens (Miq.) Miq. and it were identified as compound-1 [tetrahydro-2-(hydroxymethyl)-6-(terahydro-3,4-dihydroxy-2,5-bis(hydroxymethyl)fura-2-yloxy)2H-pyran-3,4,5 triol], compound-2 [dihydroxy-2-(3, 4, 5) trihydroxyphenyl) chromenylium-2-4) methoxy-6methyloxane-3, 4, 5 triol] and compound-3 [6- methoxycyclohexane-1,2,3,4,5-pentaol]. The structures of the compounds were elucidated by means of ${ }^{1} \mathrm{H}-\mathrm{NMR},{ }^{13} \mathrm{C}-\mathrm{NMR}$ and DEPT-135 spectral data and comparison with literature reports.
\end{abstract}

Keywords: Chemical constituents; Ficus ingens (Miq).Miq.; Methanol;

DOI: $10.7176 / \mathrm{JNSR} / 9-7-07$

Publication date: April $30^{\text {th }} 2019$

\section{Introduction}

Ficus ingens commonly called fig is a plant of high medicinally values possessing many of the biological activities like antibiotic and analgesic wide spread in northern and eastern sub-Saharan Africa. with a more or less contiguous range from Senegal in the west, eastwards to Eritrea and southwards to the Eastern Cape, South Africa [1]. It is found on rock faces and outcrops, rocky slopes, riparian and wade fringes, and in dense woodlands Substrates include lava flows, coral and limestone in drier, exposed areas and sandstone or dolomite in bushveld [2]. In northern Nigeria the figs, of and in Kenya the leaves and figs, of F.ingens have been recorded as famine food [3]. In South Africa a decoction of the bark mixed with cow feed is said to increase the flow of milk [18], though the leaves have been shown to be toxic to cattle, and sometimes to sheep [4]. When ripe, the figs are readily eaten by several species of bird [5]. Ficus in genesis have different specious and many active compounds were isolated from this different specious for instance Benghalensis bark; 20-tetratriaconthene-2-one, 6 heptatriacontene-10-one, pentatriacontan-5-one, $\beta$-sit sterol, $\beta$-d-glycoside and memo inositol In addition, the fruit extract of $F$. benghalensis exhibited antitumor activity, while the methanol extract of $F$. benghalensis possesses antioxidant. F. sycomorus extracts are used in Folk medicine in the treatment of infertility and sterility in human. Ficus capensis extract was used for treatment of a zoosperm. Ficus asperifolia extract has been reported to have an estrogenic effect in female rats [6]. The chemical constituents and hepatoprotective effect of whole plant of $F$. ingens (Miq.)Miq.(Moraceae) extract against carbon tetrachloride-induced acute liver damage in male Wistar albino rats. SC injection of $\mathrm{CCl}_{4}$ to rats showed significant elevation of liver marker enzymes (ALT, AST, ALP and LDH) in their serum after $24 \mathrm{~h}$ of intoxication. The ethanol extract of $F$. ingens to take different doses $100,200 \& 400 \mathrm{mg} / \mathrm{kg}$. The results showed $400 \mathrm{mg} / \mathrm{kg}$ is significant [7].

\section{Materials and Methods}

\section{Plant Collection and Identification}

The bark of Ficus ingens (Miq.)Miq. was collected from Amuru village, Horro Guduru, Wellega Zone, Oromia Region Ethiopia, which is $383 \mathrm{~km}$ west of Addis Ababa. The plant was identified by prof. Legesse Negash and specimen was deposited at the National Herbarium (Voucher Diriba Borena 001/2015) in the department of biology, Addis Ababa University.

\section{Experimental procedures Extraction}

The collected plant material was cut in to smaller pieces to facilitate drying and dried under room temperature. The dry plant material was taken separately and grinded to a uniform size using an electric grinder. The pulverized powder $(250 \mathrm{~g})$ was successively extracted by maceration with $1000 \mathrm{ml} \mathrm{n}$ - hexane, dichloromethane, ethyl acetate, and methanol for three consecutive days each at room temperature. The extracts were filtered using WhatmanNo.1 filter paper $(150 \mathrm{~mm})$ and evaporated under vacuum to obtain the respective crude extracts. 


\section{Isolation of compounds}

The separation, isolation and purification of compounds was carried out by a gravity column chromatography using Merck silica gel $60(0.040-0.063 \mathrm{~mm})$ and monitored by thin layer chromatography (TLC; Merck $20 \times 20$ $\mathrm{cm}$ silica gel $60 \mathrm{~F} 254$ aluminum sheets). The extracts were crudely separated on a $4 \mathrm{~cm}$ diameter column using appropriate solvent systems which gave the best separation on TLC. Fraction sizes of $100 \mathrm{~mL}$ each were collected. The elution progress of each fraction and sub fractions was monitored by TLC using n-hexane, EtOAc, dichloromethane, chloroform, methanol and mixtures of different solvent system by increasing polarity of solvent depending on their TLC. Visualization of the chromatogram was achieved by spraying of appropriate reagents.

\section{Spectroscopic analysis}

Pure fractions from column chromatography were characterized by using IR, UV and nuclear magnetic resonance $\left({ }^{1} \mathrm{H}-\mathrm{NMR}{ }^{13} \mathrm{C}\right.$-NMR, DEPT and the spectra were recorded in $\mathrm{CDCl}_{3}$ and DMSO- $d_{6}$ with Tetramethylsilane (TMS) as internal standard. Complete structure determination was achieved by comparing the IR and NMR data obtained with that in literature.

\section{Isolation of compounds form methanol extract of Ficus ingens}

$4.5 \mathrm{~g}$ of $\mathrm{MeOH}$ extract was adsorbed on silica gel and charged on to column packed with silica gel using chloroform. The column was eluted using methanol: chloroform (as shown in Table 1)

Table 1: The fraction that collected using methanol: chloroform

\begin{tabular}{|l|l|l|c|l|}
\hline Fractions & \multicolumn{1}{|c|}{ Solvent } & Ratio & Yield of each fraction & Sample code \\
\hline $1-2$ & Chloroform & $100 \%$ & $10.12 \mathrm{mg}$ & F-1 and F-2are discarded \\
\hline $3-10$ & $\mathrm{MeOH}: \mathrm{CHCl}_{3}$ & $1: 9$ & $30.10 \mathrm{mg}$ & F-3 \\
\hline 11 & $\mathrm{MeOH}: \mathrm{CHCl}_{3}$ & $2: 8$ & $21.04 \mathrm{mg}$ & F-11 \\
\hline $12-13$ & $\mathrm{MeOH}: \mathrm{CHCl}_{3}$ & $3: 7$ & $14.16 \mathrm{mg}$ & F-12 \\
\hline 14 & $\mathrm{MeOH}: \mathrm{CHCl}_{3}$ & $5: 5$ & $31.31 \mathrm{mg}$ & F-14 Compound 2 \\
\hline $15-17$ & $\mathrm{MeOH}: \mathrm{CHCl}_{3}$ & $6: 4$ & $0.25 \mathrm{mg}$ & F-15 \\
\hline $18-19$ & $\mathrm{MeOH}: \mathrm{CHCl}_{3}$ & $7: 3$ & $25.31 \mathrm{mg}$ & Compound-3(F-18) \\
\hline 20 & $\mathrm{MeOH}: \mathrm{CHCl}_{3}$ & $7: 3$ & $31.32 \mathrm{mg}$ & Compound-2( F-20) \\
\hline $21-23$ & $\mathrm{MeOH}: \mathrm{CHCl}_{3}$ & $8: 2$ & $19,11 \mathrm{mg}$ & F-23 \\
\hline $24-30$ & $\mathrm{MeOH}: \mathrm{CHCl}_{3}$ & $8: 2$ & $27.13 \mathrm{mg}$ & Compound-1 (F-24) \\
\hline $31-44$ & $\mathrm{MeOH}: \mathrm{CHCl}_{3}$ & $9: 1$ & $18.00 \mathrm{mg}$ & F-31 \\
\hline $45-60$ & $\mathrm{MeOH}: \mathrm{CHCl}_{3}$ & $100 \%$ & $40.01 \mathrm{mg}$ & F-60 \\
\hline
\end{tabular}

Fractions 3-10 eluted with methanol: chloroform ratio (1:9, V/V) afforded compound 1 with a 1:1 (V/V) methanol: chloroform elution. Another fraction, F-14 was obtained which yielded compound 2 or F-14. Methanol: chloroform - (7:3) elution afforded compound 3, F-18.

\section{Characterization of the compounds}

\section{Characterization of compound 1}

Compound 1 was obtained as a white crystal from fractions F-20 and F-24. The ${ }^{1} \mathrm{H}-\mathrm{NMR}\left(400 \mathrm{MHz}, \mathrm{CDCl}_{3}\right)$ of compound 1 depicts signals which appear at $\delta_{\mathrm{H}} 5.24,5.17,5.09,3.77,3.38$ and 4.54 that were doublets, the signals which appeared at $\delta_{\mathrm{H}} 4.86,4.41,3.51$ and 3.11 were multiples and the signals at $\delta_{\mathrm{H}} 3.89$ and 3.63 that were triplets (see Table 2)

Table 2: ${ }^{1} \mathrm{H}-\mathrm{NMR}\left(400 \mathrm{MHz}, \mathrm{CDCl}_{3}\right)$ spectral data of compound 1

\begin{tabular}{|c|c|}
\hline Hydrogen atoms & ${ }^{1} \mathrm{H}-\mathrm{NMR} \delta(\mathrm{ppm})$ \\
\hline 1 & $3.77(\mathrm{~d}, 2 \mathrm{H})$ \\
\hline 2 & - \\
\hline 3 & $3.38(\mathrm{~d}, 2 \mathrm{H})$ \\
\hline 4 & 4.54 \\
\hline 5 & $5.09(\mathrm{~d}, 2 \mathrm{H})$ \\
\hline 6 & $3.89(\mathrm{t}, 3 \mathrm{H})$ \\
\hline 7 & $5.09(\mathrm{~d}, 2 \mathrm{H})$ \\
\hline 8 & $4.86(\mathrm{~m}, 3 \mathrm{H})$ \\
\hline 9 & $4.41(\mathrm{~m}, 3 \mathrm{H})$ \\
\hline 10 & $3.51(\mathrm{~m}, 3 \mathrm{H})$ \\
\hline 11 & $5.24(\mathrm{~d}, 2 \mathrm{H})$ \\
\hline 12 & $3.63(\mathrm{t}, 3 \mathrm{H})$ \\
\hline
\end{tabular}

The ${ }^{13} \mathrm{C}-\mathrm{NMR}$ spectrum of compound 1and its DEPT-135 showed a well resolved resonance of 12 carbon atoms, indicated the presence of one di-oxygenated quaternary carbons $(\mathrm{Cq})$ at $\delta_{\mathrm{C}} 104.44$ and three oxy-methylene carbons 
$\left(\mathrm{CH}_{2}-\mathrm{O}\right)$ at $\delta_{\mathrm{c}} 62.45,62.57$ and 60.89 . The spectrum showed presence of eight oxy-methine carbon signals at $\delta_{\mathrm{c}}$ $77.40,72.05,82.97,92.18,74.68,73.29,70.24$, and 77.40 are shows $\mathrm{CH}$ carbons. Table 3

Table 3: ${ }^{1} \mathrm{HNMR}^{13} \mathrm{C}$ NMR and DEPT-135 for Compound 1

\begin{tabular}{|c|c|c|c|}
\hline No & ${ }^{13} \mathrm{CNMR} \delta(\mathrm{ppm})$ & DEPT-135 $\delta(\mathrm{ppm})$ & Remark \\
\hline 1 & 62.45 & Down & $\mathrm{CH}_{2}$ \\
\hline 2 & 104.44 & - & Quaternary \\
\hline 3 & 77.40 & $\mathrm{Up}$ & $\mathrm{CH}$ \\
\hline 4 & 72.05 & $\mathrm{Up}$ & $\mathrm{CH}$ \\
\hline 5 & 82.97 & $\mathrm{Up}$ & $\mathrm{CH}$ \\
\hline 6 & 62.57 & Down & $\mathrm{CH}_{2}$ \\
\hline 7 & 92.18 & $\mathrm{Up}$ & $\mathrm{CH}$ \\
\hline 8 & 74.68 & $\mathrm{Up}$ & $\mathrm{CH}$ \\
\hline 9 & 73.29 & $\mathrm{Up}$ & $\mathrm{CH}$ \\
\hline 10 & 70.24 & $\mathrm{Up}$ & $\mathrm{CH}$ \\
\hline 11 & 77.40 & $\mathrm{Up}$ & $\mathrm{CH}$ \\
\hline 12 & 60.89 & $\mathrm{Down}$ & $\mathrm{CH}_{2}$ \\
\hline
\end{tabular}

Based on its ${ }^{1} \mathrm{H}-\mathrm{NMR},{ }^{13} \mathrm{C}-\mathrm{NMR}$ and DEPT-135 data, the compound 1 was identified as tetrahydro-2(hydroxymethyl)-6-(terahydro-3,4-dihydroxy-2,5-bis(hydroxymethyl)fura-2-yloxy)-2H-pyran-3,4,5 triol. Figure 1

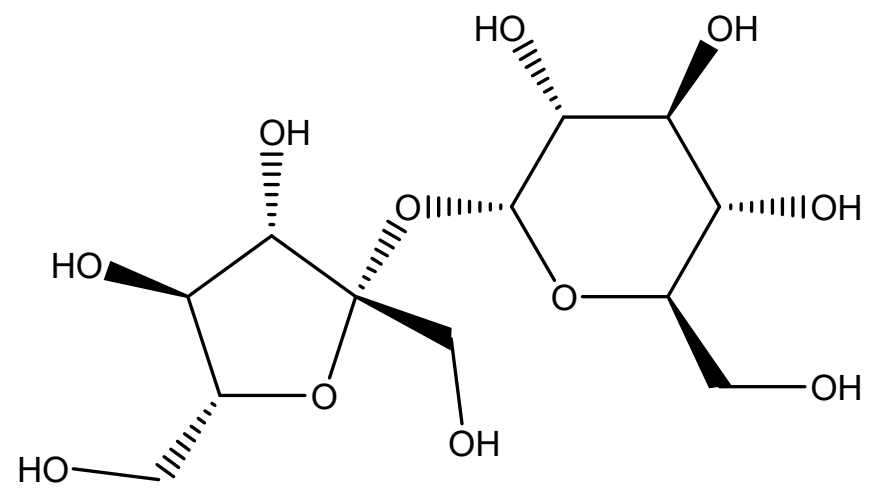

Figure 1: The proposed structure of compound 1

\section{Characterization of compound 2}

Compound 2 (F-14) $31.31 \mathrm{mg}$ was isolated using column chromatography from polar fraction as a yellow crystal. TLC analysis by methanol: chloroform (5:5) showed a single spot with $R_{f}=0.7$ staining yellow under Uv light. This compound was highly polar and ${ }^{1} \mathrm{H}-\mathrm{NMR},{ }^{13} \mathrm{C}-\mathrm{NMR}$ and DEPT-135 spectral data of the compound is listed in table 4 . 
Table 4: ${ }^{13}$ C-NMR and DEPT-135 for Compound 2 (F-14)

\begin{tabular}{|c|c|c|c|}
\hline No & ${ }^{13} \mathrm{C}-\mathrm{NMR}(\mathrm{ppm})$ & DEPT-135 & Remark \\
\hline 1 & 20.3 & $\mathrm{Up}$ & $\mathrm{CH}_{3}$ \\
\hline 2 & 29.20 & $\mathrm{Up}$ & $\mathrm{C}-\mathrm{H}$ \\
\hline 3 & 29.50 & Up & $\mathrm{CH}$ \\
\hline 4 & 54.23 & $\mathrm{Up}$ & $\mathrm{CH}$ \\
\hline 5 & 55.63 & Up & $\mathrm{CH}$ \\
\hline 6 & 56.27 & Up & $\mathrm{CH}$ \\
\hline 7 & 57.33 & $\mathrm{Up}$ & $\mathrm{CH}$ \\
\hline 8 & 63.19 & $\mathrm{Up}$ & $\mathrm{CH}$ \\
\hline 9 & 63.43 & Up & $\mathrm{CH}$ \\
\hline 10 & 63.85 & $\mathrm{Up}$ & $\mathrm{CH}$ \\
\hline 11 & 65.54 & - & Quaternary \\
\hline 12 & 68.55 & Down & Oxy methylene \\
\hline 13 & 71 & Up & $\mathrm{CH}$ \\
\hline 14 & 72 & Up & $\mathrm{CH}$ \\
\hline 15 & 73 & $\mathrm{Up}$ & $\mathrm{OH}$ \\
\hline 16 & 74 & $\mathrm{Up}$ & $\mathrm{CH}$ \\
\hline 17 & 85 & $\mathrm{Up}$ & $\mathrm{CH}$ \\
\hline 18 & 92 & Up & $\mathrm{CH}$ \\
\hline 19 & 96 & $\mathrm{Up}$ & $\mathrm{CH}$ \\
\hline 20 & 103 & Up & $\mathrm{CH}$ \\
\hline 21 & 104.95 & & Quaternary \\
\hline 22 & 109 & Up & $\mathrm{CH}$ \\
\hline 23 & 112 & $\mathrm{Up}$ & $=\mathrm{CH}$ \\
\hline 24 & 114 & $\mathrm{Up}$ & \\
\hline 25 & 138.08 & - & Quaternary \\
\hline 26 & 152.88 & - & Quaternary \\
\hline 27 & 171 & - & Quaternary \\
\hline
\end{tabular}

The ${ }^{13} \mathrm{C}-\mathrm{NMR}$ and DEPT-135 indicates that compound 2 (F-14) has 27 carbon atoms. The spectra showed at $\mathrm{C}_{\delta} 20.31$ oxy methyl carbons, the spectra showed at $\delta_{\mathrm{c}} 65.54,104.95,138.08,152.88$, and 171.89 are shows quaternary carbons. The spectra showed at $\delta_{\mathrm{c}} 63$ shows $\mathrm{CH}_{2}$.

In the IR (KBr) spectrum, the absorption at $3408 \mathrm{~cm}^{-1}$ shows the presence of alcohol and the absorption at the $2924 \mathrm{~cm}^{-1}$ showed the of alkane $\mathrm{CH}_{3}$. A strong absorption and at $1723 \mathrm{~cm}^{-1}$ indicated the presence of ester functional group. And a week band at $1621 \mathrm{~cm}^{-1}$ showed the presence of alkene $\mathrm{C}=\mathrm{C}$ stretch. The presence of absorption bands $1078 \mathrm{~cm}^{-1}$ illustrated $\mathrm{C}-\mathrm{O}$ stretches of ester functional group, a band at $625 \mathrm{~cm}^{-1}$ showed the presence of tri substituted double bond.

Based on the above NMR and IR spectrum data the structure was proposed for the compound 2 (F-14) was identified as dihydroxy-2-(3, 4, 5) trihydroxyphenyl) chromenylium-2-4) methoxy-6-methyloxane-3, 4, 5 triol. Figure 2<smiles>COc1cc(C(O)C(COC(=O)/C=C/c2c(O)cc(O)cc2O)Oc2c(OC)cc(O)cc2OC)cc(OC)c1O</smiles>

Figure 2: The proposed structure of compound 2 


\section{Characterization of compound 3}

The ${ }^{1} \mathrm{H}-\mathrm{NMR}$, spectral data of compound 3 depicts the signals appearing at $\delta_{\mathrm{H}} 4.61,4.33,3.77,3.62,3.41,3$ and 3.21 as multiples. The signal at $\delta_{\mathrm{H}} 5.1$ is appeared as a singlet. Table 5

\section{Table 5: ${ }^{1} \mathrm{H}-\mathrm{HMR}\left(400 \mathrm{MHz}, \mathrm{CDCl}_{3}\right)$ spectral data of compound 3}

\begin{tabular}{|l|l|}
\hline Hydrogen atoms & ${ }^{1} \mathrm{H}-\mathrm{NMR} \delta(\mathrm{ppm})$ \\
\hline 1 & $3.77(\mathrm{~m}, 1 \mathrm{H})$ \\
\hline 2 & $3.4(\mathrm{~m}, 1 \mathrm{H})$ \\
\hline 3 & $3.21(\mathrm{~m}, 1 \mathrm{H})$ \\
\hline 4 & $3.6(\mathrm{~m}, 1 \mathrm{H})$ \\
\hline 5 & $4.3(\mathrm{~m}, 1 \mathrm{H})$ \\
\hline 6 & $5.12(\mathrm{~s}, 3 \mathrm{H})$ \\
\hline 7 & $4.6(\mathrm{~m}, 1 \mathrm{H})$ \\
\hline
\end{tabular}

The singlet signal appears at $\delta_{\mathrm{H}} 5.12$ indicates the presence of methyl group bearing 3 proton attached to oxycarbon. The multiple signals at $\delta_{\mathrm{H}} 4.61,4.33,3.77,3.62,3.41,3$ and $\delta_{\mathrm{H}} 3.21$ are six methine each integrated to one proton in a ring.

${ }^{13} \mathrm{C}-\mathrm{NMR}$ and DEPT-135 Table 8 indicate that Compound 3 has 7 carbon atoms. The spectra showed at $\delta_{\mathrm{C}}$ 81.37 an oxy-methine signal $\mathrm{CH}-\mathrm{O}$ and at $\delta 57.44$ methyl carbon signal. Further, the spectra showed five oxymethine signals at $\delta 68.25,70.93,72.58,72.37$, and 73.69 .

Table 6:13C-NMR and DEPT-135 for Compound 3

\begin{tabular}{|c|c|c|c|}
\hline No & $\begin{array}{c}{ }^{13} \mathrm{C}-\mathrm{NMR} \\
\delta(\mathrm{ppm})\end{array}$ & $\begin{array}{c}\text { DEPT-135 } \\
\delta(\mathrm{ppm})\end{array}$ & Remark \\
\hline 1 & 68.25 & $\mathrm{Up}$ & $\mathrm{CH}-\mathrm{O}$ \\
\hline 2 & 70.93 & $\mathrm{Up}$ & $\mathrm{CH}-\mathrm{O}$ \\
\hline 3 & 72.58 & $\mathrm{Up}$ & $\mathrm{CH}-\mathrm{O}$ \\
\hline 4 & 72.37 & $\mathrm{Up}$ & $\mathrm{CH}-\mathrm{O}$ \\
\hline 5 & 73.69 & $\mathrm{Up}$ & $\mathrm{CH}-\mathrm{O}$ \\
\hline 6 & 81.37 & $\mathrm{Up}$ & $\mathrm{CH}-\mathrm{O}$ \\
\hline 7 & 57.44 & $\mathrm{Up}$ & $-\mathrm{OCH}_{3}$ \\
\hline
\end{tabular}

Based on the above ${ }^{1} \mathrm{H}-\mathrm{NMR}$ and ${ }^{13} \mathrm{C}$-NMR spectrum data the structure was proposed for compound 3, which is 6-methoxycyclohexane-1,2,3,4,5-pentaol. Figure 3<smiles>COC1C(O)C(O)C(O)C(O)C1O</smiles>

Figure 3: The proposed structure of compound 3

\section{Conclusion}

This work resulted in the isolation of three new compounds that is not isolated from the plant in previous study, the compound was coded as compound 1: tetrahydro-2-(hydroxymethyl)-6-(terahydro-3,4-dihydroxy-2,5bis(hydroxymethyl)fura-2-yloxy)-2H-pyran-3,4,5 triol, compound 2: (F-14) was identified as dihydroxy-2-(3, 4, 5) trihydroxyphenyl) chromenylium-2-4) methoxy-6-methyloxane-3, 4, 5 triol and compound 3: 6methoxycyclohexane-1,2,3,4,5-pentaol. The structure of the compound was characterized on the basis of spectral data $\left({ }^{1} \mathrm{H}-\mathrm{NMR},{ }^{13} \mathrm{C}-\mathrm{NMR}, \mathrm{DEPT}-135\right.$ and IR) as well as comparison with the literature data.

\section{Acknowledgement}

Authors like to thank Ato Borena Hunde and Mrs. Chaltu File who helps in the selection of this traditional medicinal plant.

\section{References}

[1] Records: 'Ficus ingens (Miq.) Miq.'Tropicos.MissouriBotanical Garden.Retrieved 4 November 2014.

[2] DeWinter, B. \&M.: kellick, D.J.B (1966).Sixty-Six Transvaal Trees.National Tree List For South Africa.pp.2425. 
[3]. Palmer, Eve (1977).Afield Guide to the trees of southern Africa, London, Johannesburg: Collins.pp.9091.ISBN 0-620-05468-9.

[4] Moggs, A.O.D (1975). Important plant of sterkfontein. Johannesburg: university of the Witwatersrand.pp.78799 ISBN o-85494-426-5

[5] Myburgh, J,G,;et al.(1994)," nervous disorder in cattle cause by the plants Ficus ingens var .ingens and Ficus cordata sub sp. Salic folia" (PDF). Orderstepoort journal of veterinary research (61):171-

176 .retrieved 5 November 2014

[6] Freedman, Robert. "famine foods: moraceae". Purdue agriculture .retrieved 6 November 2014

[7] Siti Syariah Mamat, Mohamad Fauzi Fahmi, Kamarolzama Yahya, Nur Diyana Mahmoud, Muhammad Syahmi Shahril, Krystal Feredoline Jakius Norhafizah Mohtarrudin, Siew Mooi Ching, Deny Susanti, MuhammTaher, Zainul Amiruddin Zakaria. Methanol extract of Melastoma MalabathriLeaves Exerted Antioxidant And Liver Protective Activity In Rats. BMC Complement and Alternative Medicine. (2013); $13 ; 326$. 